(C) The Author(s), 2021. Published by Cambridge University Press for the Arizona Board of Regents on behalf of the University of Arizona. This is an Open Access article, distributed under the terms of the Creative Commons Attribution licence (http://creativecommons.org/licenses/by/4.0/), which permits unrestricted re-use, distribution, and reproduction in any medium, provided the original work is properly cited.

\title{
LOCAL MARINE RESERVOIR AGE ( $\triangle$ R) RECONSTRUCTED BASED ON THE TSUNAMI DEPOSIT FROM PANGANI BAY (TANZANIA)
}

\author{
Guillaume Soulet $^{1 *}$ (D) $\cdot$ Vittorio Maselli ${ }^{2}$ (D) \\ ${ }^{1}$ IFREMER, GM, F-29280 Plouzané, France \\ ${ }^{2}$ Department of Earth and Environmental Sciences, Life Sciences Centre, Dalhousie University, Halifax, Nova Scotia \\ B3H 4R2, Canada
}

\begin{abstract}
Quantifying the local marine reservoir age $(\Delta \mathrm{R})$ and its change over time is critical for precise radiocarbon calibration of marine samples and for the study of the ocean carbon cycle. $\Delta \mathrm{R}$ values are scarce for the African coast facing the Indian Ocean, and the few values available were obtained from pre-bomb shells collected during the 19th century. Here, the $\Delta \mathrm{R}$ value for calibrated year $1110 \pm 25(1 \sigma) \mathrm{CE}$ was reconstructed from radiocarbon dating and Bayesian analysis of marine and terrestrial materials coexisting in a tsunami deposit discovered in Pangani Bay (Tanzania, western Indian Ocean coast). The reconstructed $\Delta \mathrm{R}$ of $-8 \pm 40(1 \sigma, \mathrm{n}=3)$ is similar to pre-bomb regional estimates and provides new information to investigate regional $\Delta \mathrm{R}$ change over time. The Bayesian analysis of the dated samples revises the age of the tsunami event found in Pangani Bay to 1064 $1157 \mathrm{cal} C \mathrm{CE}(95.4 \%$ confidence level) or $1110 \pm 25(1 \sigma)$ cal CE, about one century younger compared to the previous estimate. Our results indicate that the new $\Delta \mathrm{R}$ value and the proposed calibration approach can be used to refine existing chronologies in the region, with implications for paleo-environmental reconstructions and archaeological studies of Early Swahili societies.
\end{abstract}

KEYWORDS: local marine reservoir age, marine reservoir effect, Pangani Bay (Tanzania), radiocarbon Bayesian analysis, tsunami deposit.

\section{INTRODUCTION}

Deriving accurate calendar ages from the radiocarbon $\left({ }^{14} \mathrm{C}\right)$ dating of marine organisms is challenging as marine ${ }^{14} \mathrm{C}$ dates need a radiocarbon reservoir age correction, which is usually unknown. The radiocarbon reservoir age of a marine sample $(\mathrm{R}(\mathrm{t}))$ is the difference between its radiocarbon age $\left({ }^{14} \mathrm{C}_{\mathrm{m}}\right)$ and that of the atmospheric $\mathrm{CO}_{2}\left({ }^{14} \mathrm{C}_{\mathrm{atm}}\right)$ at the same calendar time (t) (Stuiver and Polach 1977; Ascough et al. 2005; Jull et al. 2013; Soulet et al. 2016).

$$
\mathrm{R}(\mathrm{t})={ }^{14} \mathrm{C}_{\mathrm{m}}(\mathrm{t})-{ }^{14} \mathrm{C}_{\mathrm{atm}}(\mathrm{t})
$$

At the global scale, the reservoir age in surficial ocean waters is primarily controlled by the time needed for atmospheric $\mathrm{CO}_{2}$ to exchange with surface waters plus the contribution deriving from the slow mixing with deep ocean waters containing vast stocks of old dissolved inorganic carbon (Bard 1988). Pre-bomb reservoir age in the surface ocean ranges largely between $\sim 300$ to $\sim 1000{ }^{14} \mathrm{C}$ years (Bard 1988; Reimer and Reimer 2001).

The global marine calibration curve (Marine20; Heaton et al. 2020a) is intended to calibrate ${ }^{14} \mathrm{C}$ age of marine samples into calendar ages. Marine20 has been calculated based on a global carbon cycle box model BICYCLE (Köhler and Fischer 2004, 2006; Köhler et al. 2005, 2006) and the Northern Hemisphere atmospheric calibration curve (IntCal20; Reimer et al. 2020). However, the global marine calibration curve does not account for regional/local offsets due to a variety of factors, such as upwelling, continental inputs to coastal areas, and changes in the oceanic circulation and climate (Bard 1988; Alves et al. 2018), which contribution can be significant (Reimer and Reimer 2001; Southon et al. 2002). Hence, from the marine calibration

\footnotetext{
*Corresponding author. Email: guillaume.soulet@ifremer.fr
} 
curve, the $\Delta \mathrm{R}$ metric can be calculated (Stuiver et al. 1986; Stuiver and Braziunas 1993; Reimer and Reimer 2017). The $\Delta \mathrm{R}$ metric is called the local marine reservoir effect or the local marine reservoir age. $\Delta R(t)$ is the offset between the ${ }^{14} \mathrm{C}$ age of a marine sample $\left({ }^{14} \mathrm{C}_{\mathrm{m}}\right)$ and that of the marine calibration curve $\left({ }^{14} \mathrm{C}_{\text {Marine20 }}\right.$; the latest release being Marine20) at the same time (t):

$$
\Delta \mathrm{R}(\mathrm{t})={ }^{14} \mathrm{C}_{\mathrm{m}}(\mathrm{t})-{ }^{14} \mathrm{C}_{\text {Marine20 }}(\mathrm{t})
$$

When known a priori, $\Delta \mathrm{R}(\mathrm{t})$ can be used to correct for a local difference compared to the global marine calibration curve and calibrate the local marine ${ }^{14} \mathrm{C}$ dates into calendar ages. This requires efforts to estimate $\Delta \mathrm{R}(\mathrm{t})$ values wherever possible. An online $\Delta \mathrm{R}$ database (http:// calib.org/marine) provides pre-bomb $\Delta \mathrm{R}$ values for many locations around the world (Reimer and Reimer 2001). $\Delta \mathrm{R}$ are reconstructed from known-age of pre-bomb marine samples often obtained from museum collections (Siani et al. 2000; Southon et al. 2002; Tisnérat-Laborde et al. 2010). In practice, the pre-bomb $\Delta \mathrm{R}$ value nearest to the study area is used to calibrate locally ${ }^{14} \mathrm{C}$-dated marine materials, although the $\Delta \mathrm{R}$ can change significantly over time (Siani et al. 2001; Bondevik et al. 2006; Soulet et al. 2011; Zazzo et al. 2012; Skinner et al. 2015; Lindauer et al. 2017b). Although knowing the local $\Delta \mathrm{R}$ evolution over time is important to derive accurate calibrated ages, reconstructions of past $\Delta \mathrm{R}$ values are scarce.

There are several ways to reconstruct past $\Delta \mathrm{R}$ values (Ascough et al. 2005; Macario et al. 2015; Reimer and Reimer 2017). One of them relies on the radiocarbon analysis of same-calendarage marine and terrestrial samples (Ascough et al. 2005, 2017; Russell et al. 2011; Macario et al. 2015), which can be found, for example, at the same stratigraphic level in sediment cores (Zhao and Keigwin 2018; Soulet et al. 2019) or in archaeological sites (Ascough et al. 2005, 2017; Zazzo et al. 2012; Macario et al. 2015; Lindauer et al. 2017a, 2017b; Soulet et al. 2019; Hadden and Schwadron 2019).

Here, we incorporated a recently published large set of radiocarbon dates (Mjema 2018; Maselli et al. 2020) from an archaeological site discovered in Pangani Bay, Tanzania, western Indian Ocean (Mjema 2018; Maselli et al. 2020) (Figure 1) into a Bayesian model using OxCal v4.4.1 (Bronk Ramsey 2009a) to derive an average local $\Delta \mathrm{R}$ value at the end/ beginning of the $11 \mathrm{th} / 12$ th century $\mathrm{CE}$. To date, only one pre-bomb $\Delta \mathrm{R}$ value obtained from a shell collected in $1864 \mathrm{CE}$ has been determined for the $\sim 1400 \mathrm{~km}$ of coastline of Tanzania, including Mafia, Zanzibar, and Pemba islands (Reimer and Reimer 2001; Southon et al. 2002). Except for locations very distant from Tanzania like the Arabian Gulf (Lindauer et al. 2017a), the Gulf of Oman (Zazzo et al. 2012; Lindauer et al. 2017a, 2017b), or South Africa (Wündsch et al. 2016), to our knowledge there is no regional reconstruction of past $\Delta \mathrm{R}$ values. Hence our $\Delta \mathrm{R}$ determination for Pangani Bay can be useful to calibrate ${ }^{14} \mathrm{C}$ dates and perform age-depth modeling for the region. In Pangani Bay, the deposition of the sand layer hosting terrestrial and marine samples, as well as archaeological remains, has been related to a tsunami event that occurred about a thousand years ago and for which evidence has been found in many coastal sites facing the Indian Ocean (Rajendran et al. 2006; Monecke et al. 2008; Fujino et al. 2009; Prendergast et al. 2012), hence the name "1000-yr-old" inferred teletsunami deposit (Rajendran et al. 2006; Monecke et al. 2008; Prendergast et al. 2012; Maselli et al. 2020). Our OxCal model results indicate that this tsunami could be a century younger than previously estimated, with implications for the proper risk assessment of teletsunamis in the Indian Ocean caused by strong earthquakes from the Sumatra-Andaman subduction zone. 


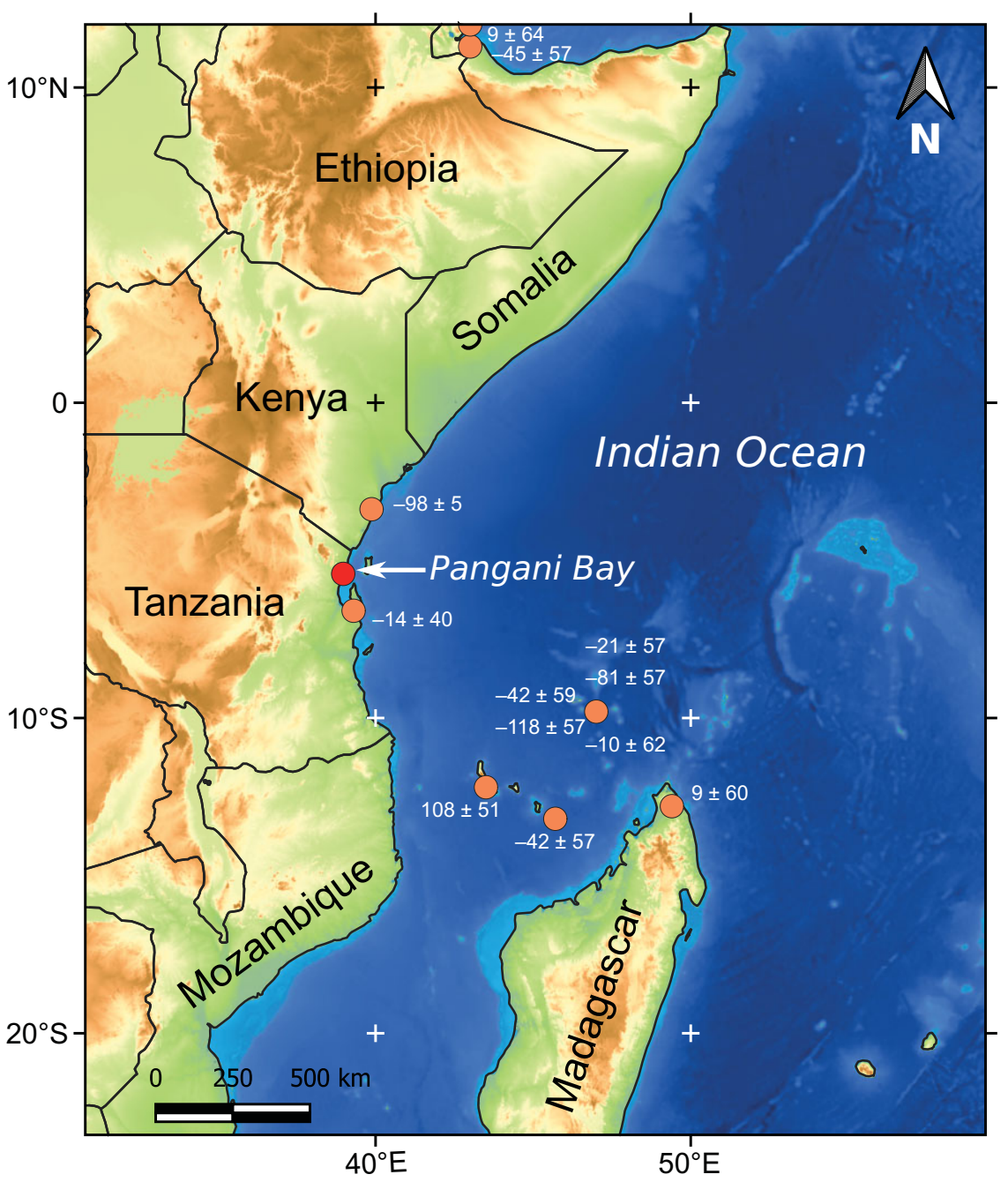

Figure 1 Map of the study area. Western Indian Ocean and the Eastern coast of Africa, including Tanzania coast and the location of the Pangani Bay (red dot) where the Swahili archaeological site was discovered (Mjema 2018; Maselli et al. 2020). Locations with pre-bomb determination of $\Delta \mathrm{R}$ values are shown (orange dots) (Cember 1989; Reimer and Reimer 2001; Southon et al. 2002; Grumet et al. 2002). All the $\Delta \mathrm{R}$ values are calculated with Marine20 calibration curve (Heaton et al. 2020; see also http://calib.org/marine/ (Reimer and Reimer 2001). (Please see electronic version for color figures.)

\section{STUDY AREA AND ARCHAEOLOGICAL CONTEXT}

Pangani Bay is located on the Tanzanian coast (western Indian Ocean, Figure 1). The bay is part of the funnel-shaped estuary of the Pangani River. On the southern bank of the bay, archaeological remains belonging to a Swahili maritime community were discovered and originally dated to $900-1100$ cal CE (Mjema 2018). Further geo-archaeological investigations were conducted in 2017, and the stratigraphy of the area was investigated through 29 pits and 2 trenches (Maselli et al. 2020). Details on the sedimentological analyses and geo-archaeological interpretations can be found in Mjema (2018) and Maselli 
et al. (2020). In brief, three main sedimentological facies were discovered. Facies 1 in the lower part of the stratigraphic logs was interpreted as an alluvial deposit of the Pangani River, above tidal influence. Facies 2, which accumulates above Facies 1, contains archaeological remains and has been interpreted as a swamp-mangrove plain that hosted the settlement of a Swahili maritime community. Facies 3 is a continuous sand deposit laying on an erosional surface and containing a mixed fossil assemblage from continental, estuarine, and marine sources including archaeological and human remains. Facies 3 has been interpreted as a tsunami deposit. Numerical modeling simulations indicated that an earthquake originated in the SumatraAndaman subduction zone was the likely source for the tsunami that hit Pangani Bay about a thousand years ago (Maselli et al. 2020).

\section{MATERIAL AND METHODS}

\section{Radiocarbon Dates}

Maselli et al. (2020) presented a set of $18{ }^{14} \mathrm{C}$ dates measured on terrestrial samples (charcoals, land snail shells, human bones, organic coating of pottery fragments) and marine samples (bivalve and gastropod shells). Measurements were carried out at the Poznan Radiocarbon Laboratory (Table 1). In the original publication, terrestrial ${ }^{14} \mathrm{C}$ dates were calibrated using the IntCal13 calibration curve (Reimer et al. 2013). Radiocarbon dates derived from marine samples were a priori corrected for reservoir effect using the nearest $(134 \mathrm{~km}$ south of the study site) pre-bomb (1864 CE) $\Delta \mathrm{R}$ value of $150 \pm 40{ }^{14} \mathrm{C} \mathrm{yr}$ (Southon et al. 2002), and calibrated using the Marine13 calibration curve (Reimer et al. 2013). The age of the tsunami layer was then estimated to a range of $942-1148$ (at $95.4 \%$ ) cal CE or $1045 \pm 50$ $(1 \sigma)$ cal CE.

The geo-archaeological context of the dated materials is detailed in the original publications (Mjema 2018; Maselli et al. 2020). The available information is useful to construct a Bayesian model using OxCal v4.4.1 (Bronk Ramsey 1995, 2009a) that integrates the geo-archaeological context and ${ }^{14} \mathrm{C}$ dates to gain refined information on the age of the tsunami event and to calculate local marine reservoir age $(\Delta \mathrm{R})$ following the approach introduced in Macario et al. (2015).

\section{Specification of the Bayesian OxCal Model}

We performed a Bayesian analysis of the $18{ }^{14} \mathrm{C}$ dates using OxCal v4.4.1 (Bronk Ramsey 1995, 2009a) based on the geo-archaeological context detailed in the original publication (Maselli et al. 2020). The deposits have relative stratigraphical order: the pre-tsunami layer (Facies 1), the tsunami layer (Facies 3), and the post-tsunami layer (Facies 2). This information can be modeled in $\mathrm{OxCal}$ as a Sequence. In the pre-tsunami (Facies 1) and post-tsunami layers (Facies 2 ), ${ }^{14} \mathrm{C}$ dates are from different pits and are therefore not in stratigraphical order with reference to each other. Hence, the ${ }^{14} \mathrm{C}$ dates in the pre- and post-tsunami layers are modeled in OxCal as a Phase model (Buck et al. 1991, 1992; Bronk Ramsey 2009a). In the tsunami layer, ${ }^{14} \mathrm{C}$-dated samples were all deposited instantaneously as an "event" in geological terms. Their stratigraphical position relative to each other has no temporal meaning regarding the time-resolution of the ${ }^{14} \mathrm{C}$ dating method. The sampling resolution of the available ${ }^{14} \mathrm{C}$ dates implies that the most appropriate model is the Phase model, which assumes that the samples were deposited at slightly different times around the tsunami event (Blockley et al. 2008). Thus, we modeled Pangani Bay ${ }^{14} \mathrm{C}$ dates as a Sequence of three Phases. 
Table 1 Pangani Bay radiocarbon dates from Maselli et al. (2020) used to constrain the Pangani Bay OxCal sequence model.

\begin{tabular}{|c|c|c|c|c|c|}
\hline Log name & Depth $(\mathrm{cm})$ & Material & Sample type & $\begin{array}{c}{ }^{14} \mathrm{C} \text { age } \\
\left({ }^{14} \mathrm{C} \text { yr BP }\right)\end{array}$ & Phase \\
\hline P2E1 & 45 & Achatina sp. & Terrestrial snail & $1450 \pm 30$ & Pre-tsunami ${ }^{\mathrm{a}}$ \\
\hline P4E1 & 35 & Achatina sp. & Terrestrial snail & $1315 \pm 30$ & Pre-tsunami ${ }^{\mathrm{a}}$ \\
\hline P2E2 & 40 & Charcoal & Terrestrial & $970 \pm 30$ & Pre-tsunami ${ }^{\mathrm{a}}$ \\
\hline P4E1 & 35 & Limicolaria sp. & Terrestrial snail & $985 \pm 30$ & Tsunami event ${ }^{b}$ \\
\hline P4E1 & 35 & Limicolaria sp. juvenile & Terrestrial snail & $1025 \pm 30$ & Tsunami event ${ }^{b}$ \\
\hline P1E2 & 28 & Pottery & Terrestrial & $1030 \pm 40$ & Tsunami event ${ }^{b}$ \\
\hline P1E2 & 28 & Human bone & Terrestrial & $1010 \pm 30$ & Tsunami event ${ }^{b}$ \\
\hline P2E1 & 63 & Charcoal & Terrestrial & $1000 \pm 30$ & Tsunami event ${ }^{b}$ \\
\hline K1 & 23 & Charcoal & Terrestrial & $1025 \pm 30$ & Tsunami event ${ }^{b}$ \\
\hline K1 & 18 & Human bone & Terrestrial & $963 \pm 28$ & Tsunami event ${ }^{\mathrm{b}}$ \\
\hline P2E2 & 47 & Melampus semiaratus & Terrestrial snail & $1560 \pm 30$ & Tsunami event ${ }^{\mathrm{b}}$ \\
\hline P3W2 & 45 & Isognomon nucleus & Marine shell & $1890 \pm 30$ & Tsunami event ${ }^{b}$ \\
\hline P3W2 & 45 & Anadara sp. & Marine shell & $1455 \pm 30$ & Tsunami event ${ }^{b}$ \\
\hline P2E1 & 60 & Anadara sp. & Marine shell & $1470 \pm 30$ & Tsunami event ${ }^{\mathrm{b}}$ \\
\hline P1S1 & 30 & Monetaria annulus & Marine shell & $1415 \pm 30$ & Tsunami event ${ }^{b}$ \\
\hline P3W2 & 75 & Charcoal & Terrestrial & $1970 \pm 30$ & Post-tsunamic \\
\hline P1S1 & 45 & Charcoal & Terrestrial & $675 \pm 30$ & Post-tsunamic \\
\hline P4E1 & 75 & Human bone & Terrestrial & $295 \pm 30$ & Post-tsunamic \\
\hline
\end{tabular}

a Samples from the alluvial deposit (facies 1 in Maselli et al. 2020).

${ }^{b}$ Samples from the tsunami deposit (facies 3 in Maselli et al. 2020).

${ }^{\mathrm{c}}$ Samples from the mangrove plain deposit (facies 2 in Maselli et al. 2020). 
Pangani Bay Sequence. The sequence is composed of the three successive phases. The Pretsunami phase contains the ${ }^{14} \mathrm{C}$ dates from the alluvial unit (Facies 1) and predates the tsunami deposit. The Tsunami phase contains the ${ }^{14} \mathrm{C}$ dates from the tsunami deposit (Facies 3). Then, the Post-tsunami phase contains the ${ }^{14} \mathrm{C}$ dates of the mangrove plain deposit that blankets and post-dates the Tsunami phase (Table 1).

Pre-tsunami Phase. Three ${ }^{14} \mathrm{C}$ dates were performed on terrestrial material from three different pits belonging to the alluvial unit (Facies 1) that predates the tsunami event. They are included in this phase. As the contact between this unit and the tsunami layer is erosional, the Pretsunami phase and the Tsunami phase are modeled as sequential, and hence linked through two Boundaries that allows the model to account for a possible hiatus between the two phases (Bronk Ramsey 2009a).

Tsunami Phase. Seven ${ }^{14} \mathrm{C}$ dates performed on terrestrial material from four different pits belong to the tsunami unit (Facies 3). An additional terrestrial ${ }^{14} \mathrm{C}$ date measured on a mangrove pulmonate snail (Melampus semiauratus) is very old compared to the other seven terrestrial dates (Table 1). Thus we performed an outlier analysis (Bronk Ramsey 2009b) on this sample. We assigned this sample a low prior probability of 0.1 to be an outlier. The posterior of the outlier probability will help in deciding if this sample is actually an outlier to the model. In addition, four ${ }^{14} \mathrm{C}$ ages were obtained from the dating of marine material (bivalve and gastropod shells). These shells may have been harvested for food or ornamental purposes by local inhabitants around the time of the tsunami event (Maselli et al. 2020). Here, we assume that the shells were contemporaneous to the tsunami event within a few years, and include them in the tsunami phase. These marine samples must be corrected for local marine reservoir age. A vague prior probability for reservoir correction $\Delta \mathrm{R}$ was specified as a uniform distribution over a large range, -500 to $500{ }^{14} \mathrm{C}$ yr. It was specified as an independent parameter for each individual marine shell ${ }^{14} \mathrm{C}$ date. The posterior of the used uniform distribution provides the best $\Delta \mathrm{R}$ of the marine sample (Bronk Ramsey 2009b) considering model specifications and including the co-occurrence of the ${ }^{14} \mathrm{C}$-dated marine and terrestrial materials found in the tsunami layer (Macario et al. 2015). We assumed that the Tsunami phase and the Post-tsunami phase are contiguous, which is expressed in the model as setting a single Boundary between the two phases (Bronk Ramsey 2009a).

Post-tsunami phase. Three ${ }^{14} \mathrm{C}$ dates performed on terrestrial material from three different pits belonging to the mangrove plain unit (Facies 2) and post-dating the tsunami event, are included in this phase.

\section{Calibration Curves}

The model requires the use of an atmospheric calibration curve to calibrate the ${ }^{14} \mathrm{C}$-dated terrestrial samples and of the global marine calibration curve to calibrate the ${ }^{14} \mathrm{C}$-dated marine samples. For the global marine calibration curve, we used the Marine20 calibration curve (Heaton et al. 2020a). The location of the study area compared to the seasonal position of the Inter-Tropical Convergence Zone (ITCZ) sets the atmospheric calibration to be used (Hogg et al. 2020). When the study area is located north of ITCZ during JuneAugust, the IntCal20 calibration curve must be used (Reimer et al. 2020). Conversely, when the study area is located south of the ITCZ during December-February, the SHCal20 calibration curve must be used (Hogg et al. 2020). If the study area is located in between these two seasonal positions of the ITCZ, then a mixed calibration curve should be used 


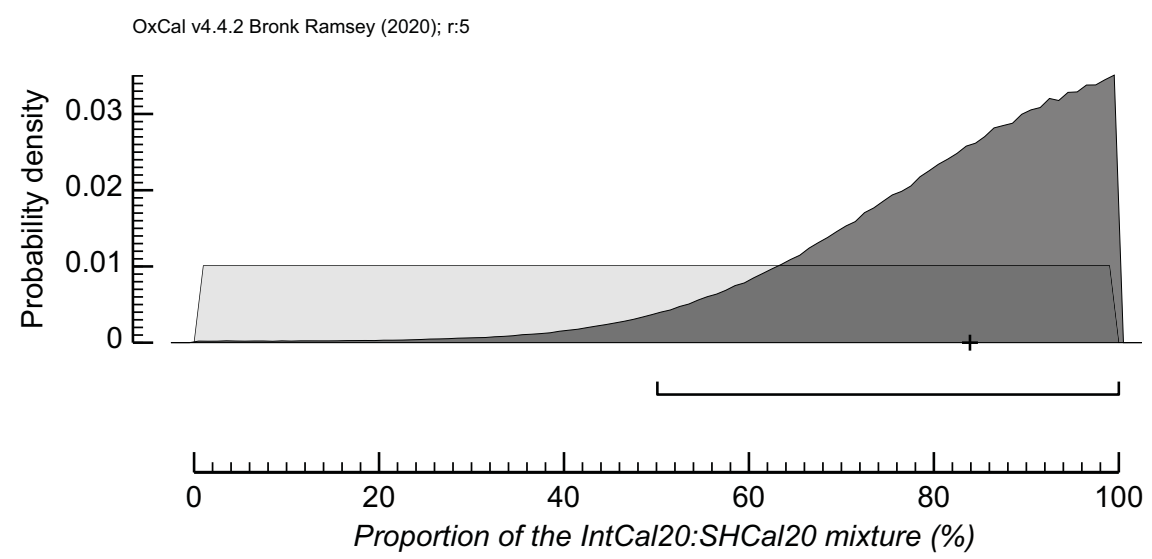

Figure 2 Prior density probability (light gray) and posterior density probability (dark gray) of the proportion of the IntCal20:SHCal20 mixture used in the Pangani Bay OxCal sequence model. Black cross and the black horizontal bracket are the median value and the $95.4 \%$ confidence level, respectively.

(see Figure 7 in Hogg et al. 2020). Pangani Bay is located between the two seasonal positions of the ITCZ. Consequently, we used a mixed calibration curve of the IntCal20 and SHCal20 curves. The use of a mixed calibration curve can be carried out using the OxCal command "Mix_Curves". The proportion must be specified. For example, a proportion of $30 \%$ means that the used atmospheric calibration curve is a mixture of $30 \%: 70 \%$ of the IntCal20 and SHCal20 calibration curves. In our case, we cannot specify a precise proportion, hence we specified a prior proportion that ranges uniformly between 0 and $100 \%$ of the IntCal20: SHCal20 mixture. This allows for any mixture of IntCal20 and SHCal20 to be tested during the OxCal run.

\section{RESULTS AND DISCUSSION}

\section{Atmospheric Calibration Curve}

The posterior proportion of the calibration curve mixture (Figure 2) shows highest probability density for the proportion $0 \%: 100 \%$ of the IntCal20:SHCal20 mixture, with a $95.4 \%$ range of $50 \%: 50 \%$ to $0 \%: 100 \%$ mixture and a median of 16\%:84\% mixture. Thus, the model results indicate that the study area is largely influenced by the Southern Hemisphere air mass. This result was expected considering that the Pangani Bay in Tanzania is located close to the position of the ITCZ during December-February (see Figure 7 in Hogg et al. 2020). Consequently, the modeled calendar ages are strongly weighted towards the Southern Hemisphere calibration curve SHCal20 due to the posterior mixed calibration curve used. For a given calendar year, the SHCal calibration curve is systematically older by a few ${ }^{14} \mathrm{C}$-decades compared to IntCal (Hogg et al. 2020). As a consequence, the new calibrated ages will be younger than those calculated in Maselli et al. (2020) as they used 100\% of IntCal13 calibration curve.

\section{Age of the Tsunami Deposit in Pangani Bay}

\section{Dated Terrestrial Material}

The age of the tsunami deposit is mainly based on the dated terrestrial material: charcoal and human bone fragments, pottery inner organic coating, land pulmonate snails (Achatina sp., Limicolaria sp.), and one mangrove pulmonate snail (Melampus semiaratus). The quality of 
the material collected for dating is thus important to obtain a reliable calendar age estimate of the tsunami, particularly because any type of material can carry issues capable of impacting the accuracy of the calendar age of the ${ }^{14} \mathrm{C}$-dated event:

- Charcoal fragments could have been reworked from older sedimentary layers or produced from the combustions of wood far older than the actual calendar age of the event (the oldwood effect; e.g. Kennett et al. 2002). Regarding the field study, it seems that ancient Swahili communities used local mangrove tree taxa as firewood (Crowther et al. 2016);

- Human diet can also influence the calendar age of ${ }^{14} \mathrm{C}$-dated bones. The contribution of fish in the diet of a human community, for example, can result in a reservoir effect, leading to older ${ }^{14} \mathrm{C}$ ages (e.g., Ascough et al. 2012; Schulting et al. 2014). However, calculation of this reservoir effect is not straightforward in the case of Pangani Bay, as well as other coastal sites in Tanzania, due to the dietary behavior of ancient Swahili communities. In detail, archaeological studies have concluded that Early Swahili had a mixed diet which included fish and shellfish but also meat from domesticated and hunted terrestrial animals, cereals, and pulses (Quintana Morales and Horton 2014; Crowther et al. 2016; Prendergast et al. 2017). The contribution of marine food to human diet at Pangani Bay leads to the possibility that the ${ }^{14} \mathrm{C}$-dated human bones could be impacted, at least partially, by a marine reservoir effect. Similarly, organic coating dated from the pottery fragment found at Pangani Bay could have been partially formed by marine food, and hence be impacted by marine reservoir effect.

- The dietary behavior of land pulmonate snails (e.g. Achatina sp. and Limicolaria sp.) can impact their ${ }^{14} \mathrm{C}$ age through an old-carbon effect via the incorporation of a ${ }^{14} \mathrm{C}$-free inorganic carbon sourced by carbonaceous rocks cropping out at surface (Matteucci et al. 2007; Hill et al. 2017; Dong et al. 2020). On substrate poor or devoid of carbonate, impact of old-carbon effect on the ${ }^{14} \mathrm{C}$ age of land snails was found to be limited if existent at all (Matteucci et al. 2007; Dong et al. 2020). The coastal plain of the Pangani Bay is covered by clastic sediments carried by the Pangani River, considered as the major supplier of freshwater and siliciclastic sediment to the coast in that area (Shaghude 2007), and tidal/ocean currents and waves. The amount of old carbonate in the sediment of Pangani Bay can be considered minimal, and, consequently, the old-carbon effect on land snails is also minimal.

- Melampus semiaratus is a detritivore mangrove pulmonate snail that feeds on mangrove leaf litter (Mckeon and Feller 2004; Perissinotto et al. 2014) and lives at the surface or in the mud under the mangrove (Brown 1971). Lindauer et al. (2017a) ${ }^{14} \mathrm{C}$ dated leaves and wood from Avicenna sp. mangrove tree in two locations of the United Arab Emirates. They showed that they were within 50 years of the actual age. Thus, providing that Melampus semiaratus feeds on mangrove leaf litter, this specie should yield similar ${ }^{14} \mathrm{C}$ age as the that of a dated event, unless it somehow incorporates older detrital particles from the mud that can be characterized by old-carbon effect of up to $2000{ }^{14} \mathrm{C}$ years (Lindauer et al. 2017a).

All the processes detailed above could potentially result in older ages than that of the dated event, the tsunami event recorded in Pangani Bay's sediments. From the eight ${ }^{14} \mathrm{C}$-dated terrestrial samples only the mangrove snail (Melampus semiaratus) yielded a ${ }^{14} \mathrm{C}$ age largely older than that of the other seven. The posterior probability that this sample is outlier to the model specifications is actually 1 (prior probability was set to 0.1 ). It is thus either reworked, as previously suggested (Maselli et al. 2020), or characterized by some large oldcarbon effect. But except this outlier, all the other seven ${ }^{14} \mathrm{C}$ dates from various terrestrial 
materials, including human bones, charcoals, pottery organic coating, and land pulmonated snails, yielded a similar ${ }^{14} \mathrm{C}$ age (Table 1$)$. These ${ }^{14} \mathrm{C}$ ages are even homogenous according to the chi-squared $\left(\chi^{2}\right)$ test (Ward and Wilson 1978) with a weighted mean of $1003 \pm 12$ ${ }^{14} \mathrm{C}$ yr BP $\left(\mathrm{n}=7 ; \mathrm{T}=4.0 ; \chi_{0.05}^{2}=12.6\right)$. Seven samples out of eight from various materials yielding a homogenous ${ }^{14} \mathrm{C}$ age strongly indicate that they are accurately dating the tsunami event in Pangani Bay.

\section{Modeled Calendar Age of the Tsunami Deposit}

Modeled calendar ages of the tsunami deposition boundaries yield a range of 1064-1140 (at 95.4\%) cal CE for the onset of tsunami deposition and a range of 1089-1157 (at 95.4\%) cal $\mathrm{CE}$ for its end. This gives a modeled age for the tsunami of 1064-1157 (at 95.4\%) cal CE or $1110 \pm 25(1 \sigma)$ cal CE (Figure 3 ), one century younger compared to the estimate presented in Maselli et al. (2020). In details, using the same ${ }^{14} \mathrm{C}$ dataset, Maselli et al. (2020) calibrated each individual ${ }^{14} \mathrm{C}$ ages of the dated terrestrial materials found in the tsunami layer with Calib 7.1 software using IntCal13 calibration curve. They estimated a calendar age of $942-1148$ (at $95.4 \%$ ) cal CE or $1045 \pm 50(1 \sigma)$ cal CE and referred the event as the "1000-yr-old" tsunami. For comparison with Maselli et al. (2020) approach, we used the OxCal model described above imposing a $100 \%$ of IntCal20 as the calibration curve. We obtained a similar modeled calendar range of 1000-1060 (at 95.4\%) cal CE, or $1015 \pm 15(1 \sigma)$ cal CE.

The discrepancy between Maselli et al. (2020) estimate and our revised estimate for the age of the tsunami is due the calibration curve used. Maselli et al. (2020) used the North Hemisphere (NH) IntCal13 calibration curve to estimate the age of the tsunami while our results are mostly based on the South Hemisphere (SH) SHCal20 calibration curve. There is not much individual difference between the 2013 and the 2020 releases of the IntCal and SHCal calibration curves for the considered period (Heaton et al. 2020b; Hogg et al. 2020). Instead there are small differences between $\mathrm{NH}$ and $\mathrm{SH}$ atmospheric ${ }^{14} \mathrm{C}$ concentrations; the $\mathrm{SH}$ atmosphere being ${ }^{14} \mathrm{C}$-depleted compared to $\mathrm{NH}$ atmosphere as a result of the higher sea-air $\mathrm{CO}_{2}$ transfer from the larger surface area of the SH oceans (Lerman et al. 1970; Rodgers et al. 2011; Hogg et al. 2020). It results that SH atmosphere (SHCal) ${ }^{14} \mathrm{C}$ ages are older by $36 \pm 27{ }^{14} \mathrm{C}$ yr compared to those of the NH atmosphere (IntCal) (Hogg et al. 2020). In practice, the calibrated age of the same ${ }^{14} \mathrm{C}$ age will be younger using $\mathrm{SHCal}$ compared to using IntCal, which is why the age of the tsunami calculated by Maselli et al. (2020) is a century older compared to our new estimate.

Pangani Bay's tsunami has been correlated to several tsunami deposits discovered in the Eastern Indian Ocean from India (Rajendran et al. 2006), Andaman and Nicobar Islands (Rajendran et al. 2007), Sumatra (Monecke et al. 2008), and Thailand (Fujino et al. 2009). These field sites yielded ${ }^{14} \mathrm{C}$ ages for the dated terrestrial material of around $1000{ }^{14} \mathrm{C}$ yr $\mathrm{BP}$, similar to Pangani Bay ${ }^{14} \mathrm{C}$ dates. Because all samples were calibrated using the Northern Hemisphere IntCal calibration curve, for consistency Maselli et al. (2020) used the same approach. Thus, the tsunami-layers correlation with trans Indian Ocean field sites is still valid. However, all these sites, including Pagani Bay, are close to the seasonal southernmost position of the ITCZ and thus in a zone where the Southern Hemisphere SHCal calibration curve should have been used (Hogg et al. 2020), or at least as a mixed calibration with IntCal (Hogg et al. 2020). Consequently, we suggest that the calendar age of the tsunami deposits found along the coastlines of the Indian Ocean (Rajendran et al. 2006, 2007; Monecke et al. 2008; Fujino et al. 2009) should be revised following the approach proposed 


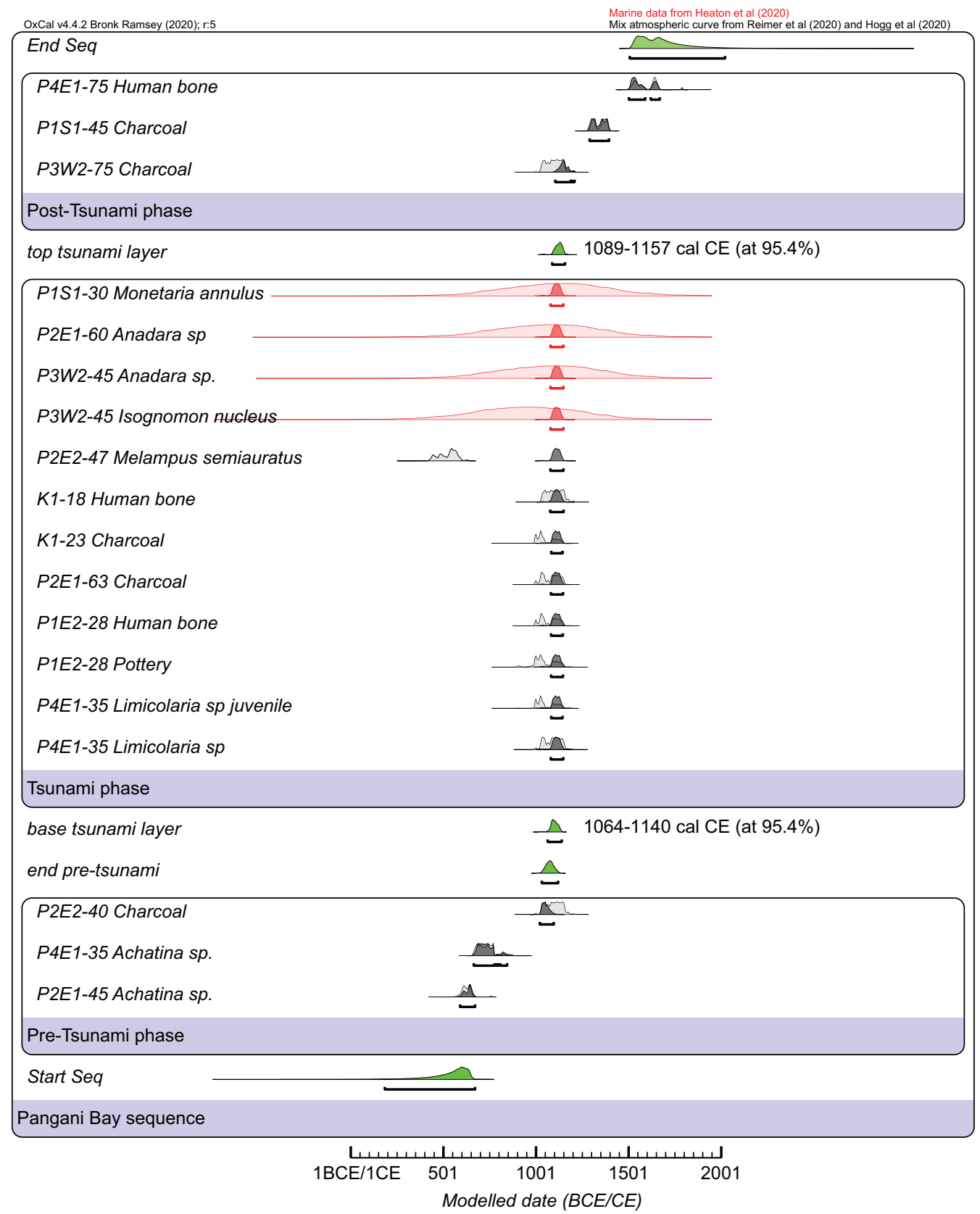

Figure 3 Pangani Bay OxCal sequence model and results of the modeled ${ }^{14} \mathrm{C}$ ages. Prior density probabilities are shown as light distributions; posterior density probabilities are shown as dark distributions; posterior $95.4 \%$ confidence levels are shown as horizontal brackets. Terrestrial samples were calibrated/modeled using the IntCal20: SHcal20 atmospheric mixed curve ((Hogg et al. 2020; Reimer et al. 2020); Figure 2 and section "Calibration Curves Used") and are shown as the light/dark grey distributions. Among these samples, P2E2-47 Melampus semiauratus was found to be outlier to the model specifications (prior probability of being an outlier was set to 0.1 , and posterior probability of being an outlier was 1). Marine samples were calibrated/modeled using Marine20 calibration curve (Heaton et al. 2020b) and are shown as light/dark red distributions. OxCal modeled boundaries are in green. 
in this study, and that the calibrated age for the deposit in Pangani Bay should be revised to 1064-1157 (at 95.4\%) cal CE or $1110 \pm 25(1 \sigma)$ cal CE. Our findings point to the need of introducing a standardised procedure for radiocarbon calibration of tsunami deposits that may allow the comparison of different sites while minimizing the uncertainty. This is particularly important when investigating teletsunami deposits and assessing their recurrence time and risk.

\section{Local $\Delta \mathbf{R}$ Values in Pangani Bay}

\section{Dated Marine Material}

Dietary behavior and habitat of the dated marine molluscs can impact their ${ }^{14} \mathrm{C}$ age and their reconstructed local marine reservoir age value (e.g., Reimer and Reimer 2001; Lindauer et al. 2017a):

- Monetaria annulus (a cowrie) is a gastropod found in shallow water in the intertidal zone, in tide pools, under stones or among seagrass. It can live in rocky, muddy, or sandy substrates (Villamor and Yamamoto 2015). It is a herbivorous grazer feeding on algae and seagrass (Passamonti 2015; Villamor and Yamamoto 2015).

- Isognomon nucleus is a byssally attached bivalve living in mangroves (Benthotage et al. 2020) or exposed depression or crevices of surface beach rocks (Ubukata 2003). It is a filter feeding species dependent on marine carbon source.

- Anadara sp. lives in intertidal mudflats in lagoons and estuaries and is a filter feeding specie (Azzoug et al. 2012; Petchey et al. 2013).

All three species used here to reconstruct the reservoir age of the local coastal ocean at Pangani Bay are strongly dependent on marine carbon sources, as such they should faithfully record the ${ }^{14} \mathrm{C}$ composition of the marine water in which they lived, unless the samples are reworked.

When using marine materials to reconstruct local marine reservoir age in archaeological context (Zazzo et al. 2012; Macario et al. 2015; Ascough et al. 2017; Lindauer et al. 2017b), it is important to keep in mind that they can have been harvested for food or ornamental purposes and be slightly older (up to some years) than the dated event, an offset that has to be considered as reasonable. This justifies the use of the Phase model which assumes that the samples were deposited at slightly different times around the dated event (Blockley et al. 2008; Macario et al. 2015; Hadden and Schwadron 2019). In contrast, the marine samples could have been reworked from older sediment layers and thus have an age largely older than the dated event, which results in spurious high $\Delta \mathrm{R}$ values. This can be tested through checking the homogeneity of the dated marine samples (Table 1). Three out of the four marine samples used to reconstruct the local marine reservoir age had a ${ }^{14} \mathrm{C}$ age homogenous according to the chi-squared $\left(\chi^{2}\right)$ test (Ward and Wilson 1978) with a weighted mean of $1447 \pm 17{ }^{14} \mathrm{C} \mathrm{yr} \mathrm{BP}\left(\mathrm{n}=3 ; \mathrm{T}=1.8 ; \chi_{0.05}^{2}=6.0\right)$. Thus, among the four marine dated samples, only the Isogmonon nucleus sample seems to have been reworked, in agreement with Maselli et al. (2020).

\section{Modeled Local $\Delta R$ Values}

The use of a set of several ${ }^{14} \mathrm{C}$ dates from coexisting terrestrial and marine samples collected in a known archaeological context can provide reliable estimates of the local marine reservoir age (e.g., Ascough et al. 2005, 2017; Zazzo et al. 2012; Macario et al. 2015; Lindauer et al. 2017b; Soulet et al. 2019; Hadden and Schwadron 2019). The method used here follows the one 
Table 2 Modeled local marine reservoir age $(\Delta \mathrm{R})$ at the time of the tsunami event CE $1120 \pm$ $25(1 \sigma)$.

\begin{tabular}{lcllll}
\hline Log name & Depth $(\mathrm{cm})$ & Material & Sample type & $\begin{array}{c}{ }^{14} \mathrm{C} \text { age } \\
\left({ }^{14} \mathrm{C} \text { yr BP }\right)\end{array}$ & $\begin{array}{c}\Delta \mathrm{R}\left({ }^{14} \mathrm{C} \text { yr }\right) \\
(\text { mean } \pm 1 \sigma)\end{array}$ \\
\hline P3W2 & 45 & Isognomon nucleus & Marine shell & $1890 \pm 30$ & $435 \pm 70$ \\
P3W2 & 45 & Anadara sp. & Marine shell & $1455 \pm 30$ & $0 \pm 70$ \\
P2E1 & 60 & Anadara sp. & Marine shell & $1470 \pm 30$ & $15 \pm 70$ \\
P1S1 & 30 & Monetaria Annulus & Marine shell & $1415 \pm 30$ & $-40 \pm 70$ \\
\hline
\end{tabular}

OxCal v4.4.2 Bronk Ramsey (2020); r:5

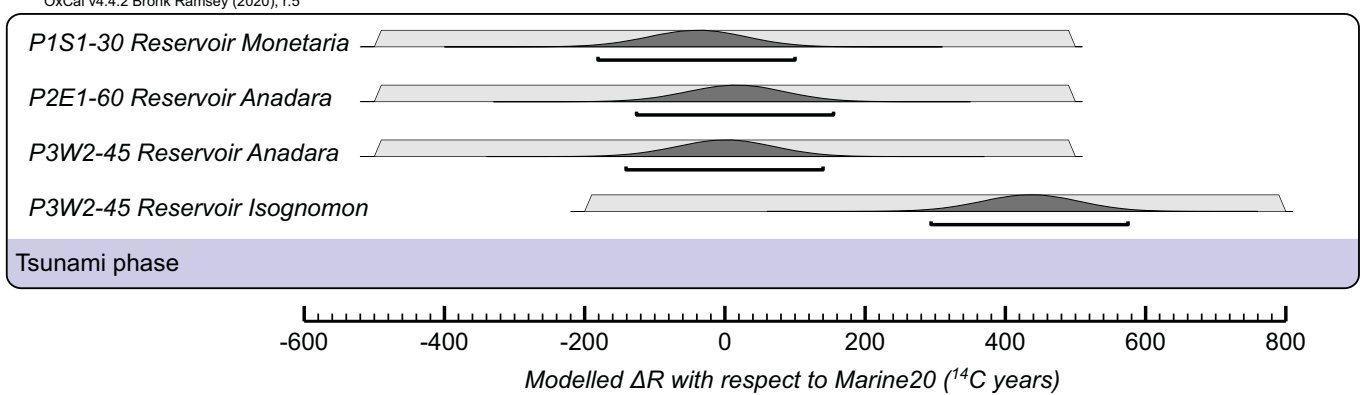

Figure 4 Prior uniform density probability (light grey) and posterior density probability (dark grey) of the $\Delta \mathrm{R}$ values of the marine samples from the Pangani Bay OxCal sequence model. Black horizontal brackets are the $95.4 \%$ confidence level of the posterior density probability (numerical values are available in Table 2).

outlined in Macario et al. (2015) and Hadden and Schwadron (2019). The basic assumption is that the terrestrial and marine samples collected from the same archaeological layer are contemporaneous, or at least considered contemporaneous with respect to ${ }^{14} \mathrm{C}$ dating uncertainties. In the case of the Pangani Bay tsunami deposit, ${ }^{14} \mathrm{C}$ dates on terrestrial samples (charcoals, organic coating of pottery sherds and human bones) were considered as best representing the age of the tsunami event (Maselli et al. 2020). Charcoals probably originate from domestic fire pits and were then transported by the tsunami waves (Maselli et al. 2020). Human remains often with broken bones were discovered in random locations and could be the result of transport by strong currents (Maselli et al. 2020), while the absence of traditional funerary burial could be explained by unexpected death (Mjema 2018). Radiocarbon dates on marine samples may not be exactly contemporaneous to the tsunami event, as they could have been harvested for food or ornamental purposes (Maselli et al. 2020). The quality and validity of the used ${ }^{14} \mathrm{C}$-dated terrestrial and marine materials have been discussed above separately.

Posterior $\triangle \mathrm{R}$ values (Table 2) for three shells out of the four collected from the tsunami layers are homogenous according to the chi-squared $\left(\chi^{2}\right)$ test (Ward and Wilson 1978) with a weighted mean of $-8 \pm 40{ }^{14} \mathrm{C}$ yr $\left(1 \sigma, \mathrm{n}=3 ; \mathrm{T}=0.3 ; \chi_{0.05}^{2}=6\right)$ compared to Marine20 calibration curve (Figure 4; Table 2). This value from the $1110 \pm 25(1 \sigma)$ cal CE tsunami deposit is close to pre-bomb value of $-14 \pm 40(1 \sigma){ }^{14} \mathrm{C}$ yr obtained from a shell that was collected in Zanzibar only $134 \mathrm{~km}$ from Pangani Bay in $1864 \mathrm{CE}$ (Southon et al. 2002). Note that this $\Delta \mathrm{R}$ value has been updated and reported compared to Marine20 (Reimer and Reimer 2001; 
Heaton et al. 2020a; http://calib.org/marine/). This result indicates that the local marine reservoir age may have remained regionally constant over the last millennium, although a higher resolution of $\Delta \mathrm{R}$ reconstruction could reveal transient changes over the period considered.

One $\Delta \mathrm{R}$ value (Isogmonon nucleus) was found to be higher compared to the homogenous group (Figure 4; Table 2). This could be explained as a short rapid increase in the local marine reservoir age, or instead, and more likely, as a spurious value calculated from a reworked shell. The original publication interprets this specific sample as a shell eroded by the tsunami wave from older sediments and transported inland (Maselli et al. 2020).

\section{CONCLUSIONS}

We used Bayesian modeling of a large set of terrestrial and marine ${ }^{14} \mathrm{C}$ dates implemented in OxCal considering the geo-archaeological context of a Swahili settlement found in Pangani Bay (Tanzania) in order to reconstruct a new local marine reservoir age of $-8 \pm 40(1 \sigma){ }^{14} \mathrm{C}$ yr with respect to the Marine20 calibration curve for the end/beginning of the 11 th/12th century. The $\Delta \mathrm{R}$ value is similar to that derived from a pre-bomb shell collected during the 19th century about $130 \mathrm{~km}$ from Pangani Bay and indicates that the marine reservoir age could have remained locally constant over the last millennium, although more $\Delta R$ value reconstructions are needed to confirm this pattern. Using the appropriate calibration curve for the studied site (SHCal20), we revise the age of the Indian Ocean "1000-yr-old" teletsunami event to $1064-1157$ (at $95.4 \%$ ) cal CE or $1110 \pm 25(1 \sigma)$ cal CE. Tsunami deposits can occur along all coastlines of the Indian Ocean. Although very distant from each other, some of these deposits can have been generated by the same tsunamigenic event. To accurately date these teletsunami events and propose robust correlations between deposits found at different coastal sites, we suggest integrating a set of several terrestrial ${ }^{14} \mathrm{C}$ dates sampled in a secure geological/geo-archeological context encompassing the event into a Bayesian model and to use the appropriate calibration curve. In the Indian Ocean, the Southern Hemisphere SHCal calibration curve must be used if the study site is located south of the ITCZ during December-February, and a mixed calibration curve with IntCal if the study site is located north of this ITCZ seasonal position (Hogg et al. 2020).

\section{ACKNOWLEDGMENTS}

GS thanks Quentin Dubois-Dauphin from Ifremer for assistance in drafting Figure 1. VM acknowledges support from the NSERC Discovery Grant (RGPIN-2020-04461). We thank Editor Hua and two anonymous reviewers for comments and suggestions that improved the manuscript substantially.

\section{REFERENCES}

Alves EQ, Macario K, Ascough P, Bronk Ramsey C. 2018. The worldwide marine radiocarbon reservoir effect: definitions, mechanisms, and prospects. Reviews of Geophysics 6:1-28. doi: 10.1002/ 2017RG000588.

Ascough PL, Church MJ, Cook GT. 2017. Marine radiocarbon reservoir effects for the mesolithic and medieval periods in the western isles of Scotland. Radiocarbon 59(1):17-31.

Ascough P, Cook G, Dugmore A. 2005. Methodological approaches to determining the marine radiocarbon reservoir effect. Progress in Physical Geography 29(4):532-547.

Ascough PL, Church MJ, Cook GT, Dunbar E, Gestsdóttir H, McGovern TH, Dugmore AJ, Fridriksson A, Edwards KJ. 2012. Radiocarbon reservoir effects in human bone collagen from northern Iceland. Journal of Archaeological Science 39(7):2261-2271.

Azzoug M, Carré M, Schauer AJ. 2012. Reconstructing the duration of the West African Monsoon season from growth patterns and isotopic signals of 
shells of Anadara senilis (Saloum Delta, Senegal). Palaeogeography, Palaeoclimatology, Palaeoecology 346-347: 145-152.

Bard E. 1988. Correction of accelerator mass spectrometry ${ }^{14} \mathrm{C}$ ages measured in planktonic foraminifera: paleoceanographic implications. Paleoceanography 3(6):635-645.

Benthotage C, Cole VJ, Schulz KG, Benkendorff K. 2020. A review of the biology of the genus Isognomon (Bivalvia; Pteriidae) with a discussion on shellfish reef restoration potential of Isognomon ephippium. Molluscan Research 40(4):286-307.

Blockley SPE, Bronk Ramsey C, Pyle DM. 2008. Improved age modeling and high-precision age estimates of late Quaternary tephras, for accurate palaeoclimate reconstruction. Journal of Volcanology and Geothermal Research 177:251262.

Bondevik S, Mangerud J, Birks HH, Gulliksen S, Reimer PJ. 2006. Changes in North Atlantic radiocarbon reservoir ages during the Allerod and Younger Dryas. Science 312(5779):1514-1517.

Bronk Ramsey C. 1995. Radiocarbon calibration and analysis of stratigraphy: the OxCal program. Radiocarbon, 37(2):425-430.

Bronk Ramsey C. 2009a. Bayesian analysis of radiocarbon dates. Radiocarbon 51(1):337-360.

Bronk Ramsey C. 2009b. Dealing with outliers and offsets in radiocarbon dating. Radiocarbon 51(3): 1023-1045.

Brown DS. 1971. Ecology of gastropoda in a South African mangrove swamp. Journal of Molluscan Studies 39(4):263-279.

Buck CE, Kenworthy JB, Litton CD, Smith AFM. 1991. Combining archaeological and radiocarbon information: a Bayesian approach to calibration. Antiquity 65(249):808-821.

Buck CE, Litton CD, Smith AFM. 1992. Calibration of radiocarbon results pertaining to related archaeological events. Journal of Archaeological Science 19(5):497-512.

Cember R. 1989. Bomb radiocarbon in the Red Sea: a medium-scale gas exchange experiment. Journal of Geophysical Research 94(C2):2111. doi: 10. 1029/JC094iC02p02111.

Crowther A, Faulkner P, Prendergast ME, Quintana Morales EM, Horton M, Wilmsen E, KotarbaMorley AM, Christie A, Petek N, Tibesasa R, Douka K, Picornell-Gelabert L, Carah X, Boivin N. 2016. Coastal subsistence, maritime trade, and the colonization of small offshore islands in Eastern African prehistory. The Journal of Island and Coastal Archaeology 11(2):211-237.

Dong J, Cheng P, Eiler J. 2020. Implications of the apparent ${ }^{14} \mathrm{C}$ age of cultured Achatina fulica and the spatial features of ${ }^{14} \mathrm{C}$ ages among modern land snail shells in China. Palaeogeography, Palaeoclimatology, Palaeoecology 545:109654. doi: 10.1016/j.palaeo. 2020.109654
Fujino S, Naruse H, Matsumoto D, Jarupongsakul T, Sphawajruksakul A, Sakakura N. 2009. Stratigraphic evidence for pre-2004 tsunamis in southwestern Thailand. Marine Geology 262(1-4):25-28.

Grumet NS, Guilderson TP, Dunbar RB. 2002. Meridional transport in the Indian Ocean traced by coral radiocarbon. Journal of Marine Research 60(5):725-742.

Hadden CS, Schwadron M. 2019. Marine reservoir effects in Eastern Oyster (Crassostrea Virginica) from southwestern Florida, USA. Radiocarbon 61(5):1501-1510.

Heaton TJ, Köhler P, Butzin M, Bard E, Reimer RW, Austin WEN, Bronk Ramsey C, Grootes PM, Hughen KA, Kromer B, Reimer PJ, Adkins J, Burke A, Cook MS, Olsen J, Skinner LCC. 2020a. Marine20 - the marine radiocarbon age calibration curve $(0-55,000$ cal BP). Radiocarbon 62(4):779-820.

Heaton TJ, Blaauw M, Blackwell PG, Bronk Ramsey C, Reimer PJ, Scott EM. 2020b. The Intcal20 appraoch to radiocarbon calibration curve construction: A new methodology using Bayesian splines and errors-in-variables. Radiocarbon 62(4):821-863.

Hill EA, Reimer PJ, Hunt CO, Prendergast AL, Barker GW. 2017. Radiocarbon Ecology of the Land Snail Helix Melanostoma in Northeastern Libya. Radiocarbon 59(5):1521-1542.

Hogg AG, Heaton TJ, Hua Q, Palmer JG, Turney CSM, Southon J, Bayliss A, Blackwell PG, Boswijk G, Bronk Ramsey C, Pearson C, Petchey F, Reimer PJ, Reimer RW, Wacker L. 2020. SHCal20 Southern hemisphere calibration, 0-55,000 years Cal BP. Radiocarbon 62(4): 759-778.

Jull AJT, Burr GS, Hodgins GWL. 2013. Radiocarbon dating, reservoir effects, and calibration. Quaternary International 299:64-71.

Kennett DJ, Lynn Ingram B, Southon JR, Wise K. 2002. Differences in ${ }^{14} \mathrm{C}$ age between stratigraphically associated charcoal and marine shell from the Archaic Period site of Kilometer 4, southern Peru: old wood or old water? Radiocarbon 44(1):53-58.

Köhler P, Fischer H. 2004. Simulating changes in the terrestrial biosphere during the last glacial/ interglacial transition: Global and Planetary Change 43(1-2):33-55.

Köhler P, Fischer H. 2006. Simulating low frequency changes in atmospheric $\mathrm{CO} 2$ during the last 740 000 years: Climate of the Past 2:57-78.

Köhler P, Fischer H, Munhoven G, Zeebe RE. 2005. Quantitative interpretation of atmospheric carbon records over the last glacial termination: Global Biogeochemical Cycles 19(4):GB4020. doi: 10.1029/2004GB002345.

Köhler P, Muscheler R, Fischer H. 2006. A modelbased interpretation of low-frequency changes in the carbon cycle during the last 120,000 years 
and its implications for the reconstruction of atmospheric $\Delta^{14} \mathrm{C}$ : Geochemistry, Geophysics, Geosystems 7(11): Q11N06. doi: 10.1029/ 2005GC001228.

Lerman JC, Mook WG, Vogel JC, Olsson IU. 1970. C14 in tree rings from different localities. In: Radiocarbon Variations and Absolute Chronology. Proceedings, XII Nobel Symposium, New York. p. 275-301.

Lindauer S, Marali S, Schöne BR, Uerpmann H-P, Kromer B, Hinderer M. 2017a. Investigating the local reservoir age and stable isotopes of shells from southeast Arabia. Radiocarbon 59(2):355-372.

Lindauer S, Santos GM, Steinhof A, Yousif E, Phillips C, Jasim SA, Uerpmann H, Hinderer M. 2017b. The local marine reservoir effect at Kalba (UAE) between the Neolithic and Bronze Age: an indicator of sea level and climate changes. Quaternary Geochronology 42:105-116.

Macario KD, Souza RCCL, Aguilera OA, Carvalho C, Oliveira FM, Alves EQ, Chanca IS, Silva EP, Douka K, Decco J, Trindade DC, Marques AN, Anjos RM, Pamplona FC. 2015. Marine reservoir effect on the Southeastern coast of Brazil: results from the Tarioba shellmound paired samples. Journal of Environmental Radioactivity 143: 14-19.

Maselli V, Oppo D, Moore AL, Gusman AR, Mtelela C, Iacopini D, Taviani M, Mjema E, Mulaya E, Che M, Tomioka AL, Mshiu E, Ortiz JD. 2020. A 1000 -yr-old tsunami in the Indian Ocean points to greater risk for East Africa. Geology 48(8):808813.

Matteucci R, Belluomini G, Manfra L. 2007. Late Holocene environmental change in the coastal southern Somalia inferred from Achatina and rhizoliths. Journal of African Earth Sciences 49:79-89.

McKeon CS, Feller IC. 2004. Supratidal fauna of Twin Cays, Belize. Atoll Research Bulletin 526:1-22.

Mjema E. 2018. Catastrophes and deaths along Tanzania's Western Indian Ocean coast during the Early Swahili period, AD 900-1100. Azania: Archaeological Research in Africa 53(2): 135-155.

Monecke K, Finger W, Klarer D, Kongko W, McAdoo BG, Moore AL, Sudrajat SU. 2008. A 1,000-year sediment record of tsunami recurrence in northern Sumatra. Nature 455(30): 1232-1234.

Passamonti M. 2015. The family Cypraeidae (Gastropoda Cypraeoidea) an unexpected case of neglected animals. Biodiversity Journal 6(1): 449-466.

Perissinotto R, Miranda N, Raw J, Peer N. 2014. Biodiversity census of Lake St Lucia, iSimangaliso Wetland Park (South Africa): Gastropod molluscs. ZooKeys 440:1-43.
Petchey F, Ulm S, David B, McNiven IJ, Asmussen B, Tomkins H, Dolby N, Aplin K, Richards T, Rowe C, Leavesley M, Mandui H. 2013. Highresolution radiocarbon dating of marine materials in archaeological contexts: radiocarbon marine reservoir variability between Anadara, Gafrarium, Batissa, Polymesoda spp. and Echinoidea at Caution Bay, Southern Coastal Papua New Guinea. Archaeological and Anthropological Sciences 5:69-80.

Prendergast AL, Cupper ML, Jankaew K, Sawai Y. 2012. Indian Ocean tsunami recurrence from optical dating of tsunami sand sheets in Thailand. Marine Geology 295-298:20-27.

Prendergast ME, Quintana Morales EM, Crowther A, Horton MC, Boivin NL. 2017. Dietary diversity on the Swahili Coast: The fauna from two Zanzibar trading locales. International Journal of Osteoarchaeology 27(4)621-637.

Quintana Morales EM, Horton M. 2014. Fishing and fish consumption in the Swahili communities of East Africa, 700-1400 CE. Internet Archaeology 37. doi:10.11141/ia.37.3.

Rajendran CP, Rajendran K, Anu R, Earnest A, Machado T, Mohan PM, Freymueller J. 2007. Crustal deformation and seismic history associated with the 2004 Indian Ocean earthquake: A perspective from the Andaman-Nicobar Islands. Bulletin of the Seismological Society of America 97(1A):S174-S191.

Rajendran CP, Rajendran K, Machado T, Satyamurthy T, Aravazhi P, Jaiswal M. 2006. Evidence of ancient sea surges at the Mamallapuram coast of India and implications for previous Indian Ocean tsunami events. Current Science 91(9):1242-1247.

Reimer PJ, Bard E, Bayliss A, Beck JW, Blackwell PG, Bronk Ramsey C, Buck CE, Cheng H, Edwards RL, Friedrich M, Grootes PM, Guilderson TP, Haflidason H, Hajdas I, Hatté C, Heaton TJ, Hoffmann DL, Hogg AG, Hughen KA, Kaiser KF, Kromer B, Manning SW, Niu M, Reimer RW, Richards DA, Scott EM, Southon JR, Staff RA, Turney CSM, van der Plicht J. 2013. IntCal13 and Marine13 radiocarbon age calibration curves $0-50,000$ years cal BP. Radiocarbon 55(4):1869-1887.

Reimer PJ, Austin WEN, Bard E, Bayliss A, Blackwell PG, Bronk Ramsey C, Butzin M, Cheng H, Edwards RL, Friedrich M, Grootes PM, Guilderson TP, Hajdas I, Heaton TJ, Hogg AG, Hughen KA, Kromer B, Manning RWW, Muscheler R, Palmer JG, Pearson C, van der Plicht J, Reimer RW, Richards DA, Scott EM, Southon JR, Turney CSM, Wacker L, Adolphi F, Büntgen U, Capano M, Fahrni SM, Fogtmann-Schulz, Friedrich R, Köhler P, Kudsk S, Miyake F, Olsen J, Reining F, Sakamoto M, Sookdeo A, Talamo S. 2020. The Intcal20 Northern hemisphere radiocarbon age 
calibration curve (0-55 cal kBP). Radiocarbon 62(4):725-757.

Reimer PJ, Reimer RW. 2001. A marine reservoir correction database and on-line interface. Radiocarbon 43(2A):461-463.

Reimer RW, Reimer PJ. 2017. An online application for $\Delta \mathrm{R}$ calculation. Radiocarbon 59(5): 1623-1627.

Rodgers KB, Mikaloff-Fletcher SE, Bianchi D, Beaulieu C, Galbraith ED, Gnanadesikan A, Hogg AG, Iudicone D, Lintner BR, Naegler T, Reimer PJ, Sarmiento JL, Slater RD. 2011. Interhemispheric gradient of atmospheric radiocarbon reveals natural variability of Southern Ocean winds. Climate of the Past 7:1123-1138.

Russell N, Cook GT, Ascough PL, Scott EM, Dugmore AJ. 2011. Examining the inherent variability of $\Delta R$ : new methods of presenting $\triangle \mathrm{R}$ values and implications for MRE studies. Radiocarbon 53(2):277-288.

Schulting RJ, Bronk Ramsey C, Bazaliiskii VI, Goriunova OI, Weber A. 2014. Freshwater reservoir offsets investigated through paired human-faunal ${ }^{14} \mathrm{C}$ dating and stable carbon and nitrogen isotope analysis at Lake Baikal, Siberia. Radiocarbon 56(3):991-1008.

Shaghude YW. 2007. Shore morphology and sediment characteristics south of Pangani River, coastal Tanzania. Western Indian Ocean Journal of Marine Science 3(2):93-104.

Siani G, Paterne M, Arnold M, Bard E, Métivier B, Tisnerat N, Bassinot F. 2000. Radiocarbon reservoir ages in the Mediterranean Sea and Black Sea. Radiocarbon 42(2):271-280.

Siani G, Paterne M, Michel E, Sulpizio R, Sbrana A, Arnold M, Haddad G. 2001. Mediterranean Sea surface radiocarbon reservoir age changes since the Last Glacial Maximum. Science 294(5548):1917-1920.

Skinner LC, McCave IN, Carter L, Fallon S, Scrivner AE, Primeau F. 2015. Reduced ventilation and enhanced magnitude of the deep Pacific carbon pool during the last glacial period. Earth and Planetary Science Letters 411:45-52.

Soulet G, Giosan L, Flaux C, Galy V. 2019. Using stable carbon isotopes to quantify radiocarbon reservoir age offsets in the coastal Black Sea. Radiocarbon 61(1):309-318.

Soulet G, Ménot G, Garreta V, Rostek F, Zaragosi S, Lericolais G, Bard E. 2011. Black Sea "Lake" reservoir age evolution since the Last Glacial- hydrologic and climatic implications. Earth and Planetary Science Letters 308(1-2):245-258.

Soulet G, Skinner LC, Beaupré SR, Galy V. 2016. A note on reporting of reservoir ${ }^{14} \mathrm{C}$ disequilibria and age offsets. Radiocarbon 58(1):205-211.

Southon J, Kashgarian M, Fontugne M, Metivier B, Yim WWS. 2002. Marine reservoir corrections for the Indian Ocean and Southeast Asia. Radiocarbon 44(1):167-180.

Stuiver M, Braziunas TF. 1993. Modeling atmospheric ${ }^{14} \mathrm{C}$ influences and ${ }^{14} \mathrm{C}$ ages of marine samples to 10,000 BC. Radiocarbon 35(1):137-189.

Stuiver M, Pearson GW, Braziunas T. 1986. Radiocarbon age calibration of marine samples back to 9000 cal yr BP. Radiocarbon 28(2B): 980-1021.

Stuiver M, Polach HA. 1977. Discussion: reporting of ${ }^{14} \mathrm{C}$ data. Radiocarbon 19(3):355-363.

Tisnérat-Laborde N, Paterne M, Métivier B, Arnold M, Yiou P, Blamart D, Raynaud S. 2010. Variability of the northeast Atlantic sea surface $\Delta^{14} \mathrm{C}$ and marine reservoir age and the North Atlantic Oscillation (NAO). Quaternary Science Reviews 29(19-20):2633-2646.

Ubukata T. 2003. A morphometric study on morphological plasticity of shell form in crevicedwelling Pterioida (Bivalvia). Biological Journal of the Linnean Society 79(2):285-297.

Villamor S, Yamamoto T. 2015. Population characteristics of Monetaria annulus (Linnaeus, 1758) (Gastropoda: Cypraeidae) from temperate to tropical areas. Aquaculture Science 63(3):273-282.

Ward GK, Wilson SR. 1978. Procedures for comparing and combining radiocarbon age determinations: a critique. Archaeometry 20(1):19-31.

Wündsch M, Haberzettl T, Meadows ME, Kirsten KL, Kasper T, Baade J, Daut G, Stoner JS, Mäusbacher R. 2016. The impact of changing reservoir effects on the ${ }^{14} \mathrm{C}$ chronology of a Holocene sediment record from South Africa. Quaternary Geochronology 36:148-160.

Zazzo A, Munoz O, Saliège J-F, Moreau C. 2012. Variability in the marine radiocarbon reservoir effect in Muscat (Sultanate of Oman) during the 4th millennium BC: reflection of taphonomy or environment? Journal of Archaeological Science 39(7):2559-2567.

Zhao N, Keigwin LD. 2018. An atmospheric chronology for the glacial-deglacial eastern Equatorial Pacific. Nature Communications 9:3077. doi: 10.1038/s41467-018-05574-x. 


\section{APPENDIX}

OxCal code to reproduce the results presented in this paper.

Plot()

\{

Curve("IntCa120","IntCa120.14c");

Curve("SHCal20","SHCal20.14c");

Mix_Curves("Mixed","IntCal20","SHCal20",U(0,100));

Outlier_Model(“General”,T(5),U(0,4),"t");

Sequence("Pangani Bay sequence")

\{

Boundary("Start Seq");

Phase("Pre-Tsunami phase")

\{

R_Date("P2E1-45 Achatina sp.”, 1450, 30);

R_Date("P4E1-35 Achatina sp.", 1315, 30);

R_Date("P2E2-40 Charcoal", 970, 30);

;

Boundary("End pre-tsunami");

Boundary("base tsunami layer");

Phase("Tsunami phase")

\{

R_Date("P4E1-35 Limicolaria sp", 985, 30);

R_Date("P4E1-35 Limicolaria sp juvenile", 1025, 30);

R_Date("P1E2-28 Pottery ", 1030, 40);

R_Date("P1E2-28 Human bone", 1010, 30);

R_Date("P2E1-63 Charcoal", 1000, 30);

R_Date("K1-23 Charcoal", 1025, 30);

R_Date("K1-18 Human bone", 963, 28);

R_Date(“P2E2-47 Melampus semiaratus",1560,30)

\{

Outlier("General”, 0.1);

;

Curve("Oceanic","Marine20.14c");

Delta_R("P3W2-45 Reservoir Isognomon", U(-200,800));

R_Date("P3W2-45 Isognomon nucleus", 1890, 30);

Delta_R(“P3W2-45 Reservoir Anadara", U(-500,500));

R_Date("P3W2-45 Anadara sp.", 1455, 30);

Delta_R("P2E1-60 Reservoir Anadara", U(-500,500));

R_Date("P2E1-60 Anadara sp", 1470, 30);

Delta_R("P1S1-30 Reservoir Monetaria", U(-500,500));

R_Date("P1S1-30 Monetaria annulus", 1415, 30);

;

Boundary("top tsunami layer");

Phase("Post-Tsunami phase")

\{ 
1338 G Soulet \& V Maselli

R_Date("P3W2-75 Charcoal", 970, 30);

R_Date("P1S1-45 Charcoal", 675, 30);

R_Date("P4E1-75 Human bone", 295, 30);

;

Boundary("End Seq");

;

; 